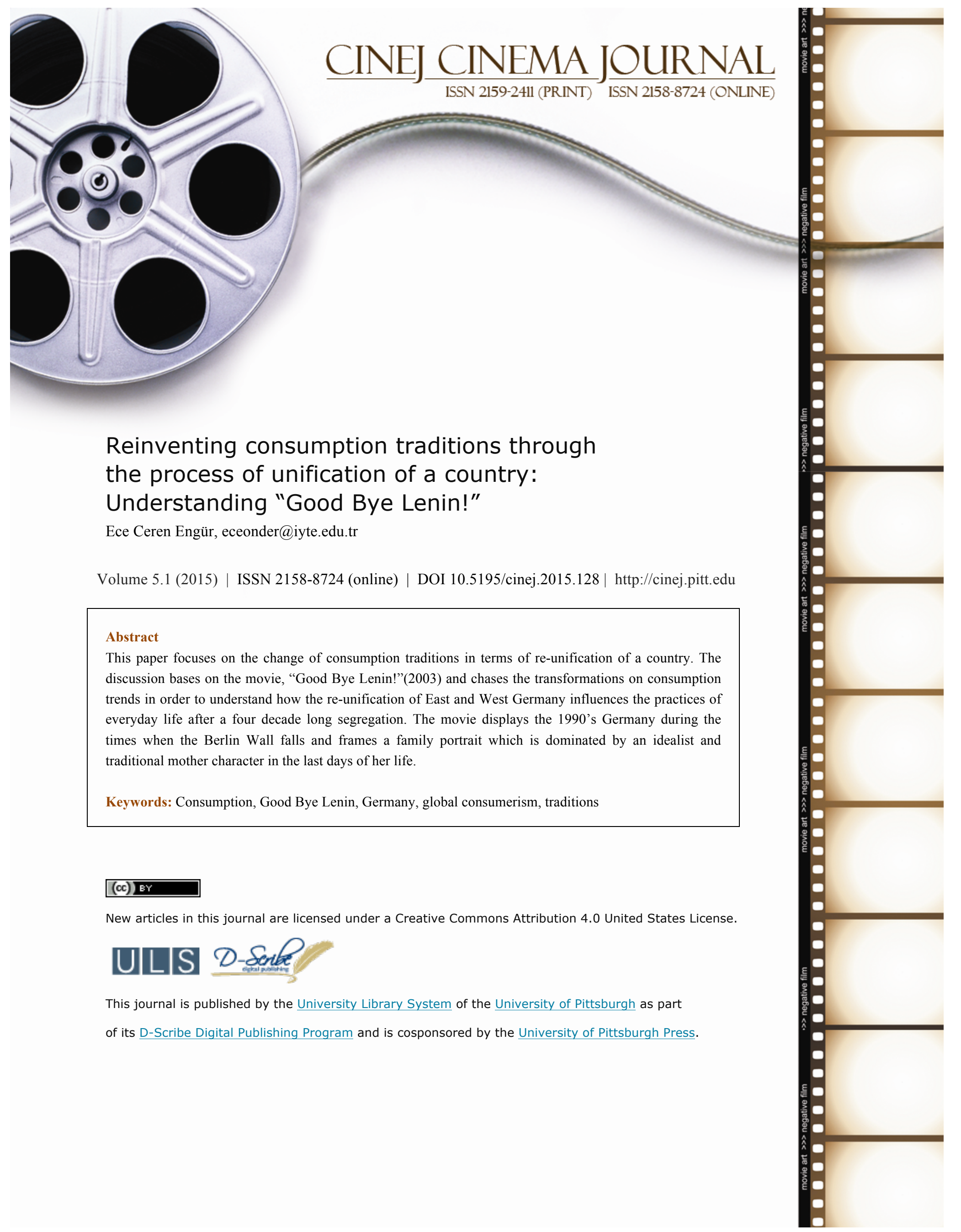




\section{Reinventing consumption traditions through the process of unification of a country: Understanding "Good Bye Lenin!"}

\section{Ece Ceren Engür}

\section{Intoduction}

Good Bye Lenin! (with red starred exclamation point) is a German manufactured movie, directed by Wolfgang Becker and released in 2003. The movie reflects a slice of life from the days of re-unification of East and West Germany in 1990. The scenario intimately shows plenty of dilemmas as like the segregated situation of the country by a wall. We see along the movie a blindly idealist mother and his family who protect her from the rapid changes of the country after her illness. The Mother is passionately nationalist and a supporter of Socialist Unity Party of East Germany. She works for the government voluntarily. After an heart attack and fall into eight month coma, the Mother misses the changes during the times of the Berlin Wall opened; the West and East side of the country penetrate with each other. This penetration is not only a physical penetration but also a socio-cultural one that causes fundamental transformations especially for the East side of the country.

We see a single mother portrait with two children who dedicates herself to her nationalistic traditions. But the progression of the traditions is not as the same as she has expected. While the wall lets through the people in, the mother confronts the shocking changes within both the lives of people and the ideologies of the politicians in her beloved socialist East Germany. Although her family, especially her son try to pretend like nothing has changed, it will be inevitable to hide the reality for all. One of the scenes of the movie reminds us the famous aphorism of Karl Marx, "All That Is Solid Melts into Air" and the title of the book 
written by Marshall Berman as well. ${ }^{1}$ In that scene the son, Alex talks with his girlfriend Lara and Lara says "It's too bad she doesn't realize any of this." Alex answers: "Well, maybe it's better that. Everything she believed in, has dissolved into air in a few months." Herewith these rapidly changing and even dissolving conditions may be considered as the indicators of modernism which is famous for its ephemerality.

\section{Understanding the Consumption Practices}

Mike Featherstone is one of the featuring authors who writes on consumer and consumption culture a lot. He notes that:

"Modern living became associated with the endless supply of new goods, to furnish more efficient homes filled with 'labour saving' devices, along with the access to new styles and fashions, coupled with a greater emphasis upon 'personality' and the presentation of self via techniques of grooming and body maintenance."2

From that point of view it is asserted that consumption practices are not only a commodity market process which also Marx calls it 'commodity production' ${ }^{3}$ but also an effort to install a lifestyle. Via media tools which Featherstone calls them 'culture industry', this life style periodically renews itself in order to motivate people for consumption. ${ }^{4}$ The promoted images are changing in a great motion and by means of technology, these images are delivered all around the world in a few minutes now. So, the words of Featherstone guide us to understand 
the idea behind the transition of German Democratic Republic to a 'new' unified Germany in the movie:

\footnotetext{
"Traditional forms of association in the family and private life as well as the promise of happiness and fulfillment, the 'yearning for a totally different other' which the best products of high culture strove for, are presented as yielding to an atomized, manipulated mass who participate in an ersatz mass-produced commodity culture targeted at the lowest common denominator." 5
}

In the abundance of commodities, people necessarily or unnecessarily fall into the seductive world of commodities and also consumption practices. Within the movie, the money also becomes a consumption product, a commodity on its own. The monetary unit of German Democratic Republic is not valid anymore. That is the time right before when Alex achieves to find his mother's savings in the kitchen cupboard. There's nothing to do except throwing these invalid money about. He talks in this way: "I felt like a commander of a submarine in the North Sea-Fleet, whose battle-hardened steel skin had sprung a leak. Every time I closed a leak, another one opened. Ariane denied being my brother in arms, the class enemy raised his Cola-flag and a fresh wind from the West blew mother's East money around my ears." (Figure 1)

Good Bye Lenin! movie can be examined from the perspective of global consumerism. According to a point of view the socialism of East Germany has been defeated on the face of 
West's capitalism. This defeat ended up with the assimilation of the existing culture rather than integration of a new culture. ${ }^{6}$

Ayşe Öncü discusses global consumerism in the context of the myth of 'ideal home' in İstanbul. She mentions briefly the changings in İstanbul especially in residential districts after 1980s just as the global economy network became free in Turkey. She clarifies the basic notions of global consumerism into three parts. ${ }^{7}$ First one she states, is to understand the universal language of the money. Commodifying everything with a monetary sign is the motto of the global era. Second is the symbolic significance of consumption practices and their ability to generate blurred meanings between contrasts as high and low; original and reproduction or the sacred and the banal. Öncü says this notion creates hybrid cultures. The last and the third one is that consumer culture houses the contemporary myths. She identifies this notion:

\footnotetext{
"A culture of consumption would mean, a culture wherein goods become the embodiment of desires, dreams, emotions, wherein subjective experiences of love, excitement, cleanliness, pleasure or freedom are objectified in goods. "8
}

Based on these notions of Öncü, in terms of understanding the global consumerism, the movie draws a perspective related to the issues on consumption culture for its audience which are mentioned above. Öncü states that in İstanbul, global consumerism have changed the daily routines of İstanbulites with its 'homogenizing' aspect. ${ }^{9}$ She adds that by promising new ways 
and creating myths, also cause a spatial and cultural fragmentation at local level. Thus, there are some threatening points as were lived in İstanbul. In the case of unification of East and West Germany, it is possible too and the director points out these threats quietly throughout the movie.

While mentioning the consumption culture and global consumerism it is significant that to mention also about the collective memory. Halbwachs expresses on the collective memory beyond the memory of individuals. ${ }^{10} \mathrm{He}$ argues that there is always a group memory that is linked to today and it is alive as well. Halbwachs says that a person can't construct his/her memories without the impacts of society. Therefore he notes that the collective memory has a social framework and it changes according to the present conditions of the society. ${ }^{11}$ The values of the era directs the way we remember and every time, we reconstruct / reproduce the past depending on these values. Halbwachs believes that "the mind reconstructs its memories under the pressure of society." So the individuals' memories can't be considered without a collective context. ${ }^{12}$ Although individual personalities are more respected in modern societies, people belong to the memory of the groups and modern individual can't be thought apart from a society.

\section{Consumption Trends in Good Bye Lenin!}


I want to discuss the movie from two modernist perspectives. First perspective is the political and ideological perspective and second is the socio cultural perspective which derives from consumption issues mostly.

Along with the movie, we see a conflict in a country which is caused by a strict separation of German society. East and West side of the country totally governed by different ideologies and their politic decisions effect the daily lives of people directly. The Berlin Wall draws the boundaries of two sides and generates a symbol of separation between East and West Germany. Up to 1990, people of two sides couldn't pass by the other German side. They were not allowed. The East German was governed by a socialist regime and closed to the foreign capitals. On the contrary the West had a federal government and the foreign capital was allowed in the country. In one of the most remarkable scenes, the mother watches the statue of Lenin while it is transported by a helicopter from its original location. This flying Lenin is the symbol of socialism and it is going into the air now in this frame (Figure 2). In this scene the Mother goes firstly to the outside from her room after her illness and she is suddenly faced with the unthinkable transformation of her ideology. We see the mother's alienation and confusion from her face when she is inwardly saying 'good bye!' to Lenin.

As a result of modernity, Eric Hobsbawm mentions about inventing traditions. He says some existing traditions are adapted and served with new connections as if they belong to the past. According to him, inventing traditions is a process related with the formalization and 
ritualization aspects of bureaucracy. Thus, for instance nationalistic or religious reasons, traditions would have constructed according to impose the rules of bureaucracy to society. ${ }^{13}$ According to Hobsbawm most of the recent traditions in our times are traditions which are invented and they have been continuing by repetition. First, Hobsbawm differs custom and tradition especially by invariance feature of traditions' and he mentions that these invented traditions have a link to past which is not real substantially but is rather suitable or relevant. ${ }^{14}$ Hobsbawm mentions that there are three main reasons that cause inventing traditions. First is enabling a cohesion within a society second is legitimizing of authority and the third is imposing the beliefs and values. ${ }^{15}$

Studying the invention of tradition has a significance for understanding the genuine history because these traditions are existing evidences. Therefore studying this topic generates an understandable connection between the past and the human. As Hobsbawm notes that:

"History is not what has actually been preserved in popular memory, but what has been selected, written, pictured, popularized and institutionalized by those whose function it is to do so. ${ }^{16}$

In modern nations there are embedded components coming from the past which are now in a paradox but understandable as well and investigating these components and also connections helps us to understand what has substituted each other; what the real reasons are. Invention of traditions generate a strong connection in order to legitimize especially the national identities. 
The new beginnings in nations try to erase the past and reproduce its own past. As Hobsbawm says:

"...revolutions and progressive movements which break with the past, by definition, have their own relevant past, though it may be cut off at a certain date... invention of traditions is an effective way of establishing national identities. "17

Because of the authorities can easily manage to impose their principles when they convince the society to their factitious traditions, the power of traditions helps to hold together the masses. Another connection between invention of traditions and construction of identities is that I think, invented traditions may reinforce the invention of the 'other'. Describing the others and holding them in contempt strengthen the dominance of the authority. For this reason dominant powers are apt to exclude different identities in order to use them for their self-promotion.

The movie presents a woman character whose life is founded on these kind of traditions. The mother character makes us feel the trauma while she is living the destruction of her traditions. She believes in the traditions undoubtedly which the politicians have invented for her and also for the society.

The ideological decisions also affect the social lives of people. To understand the sociocultural practices related with the consumption issues there are quite a bit scenes in the movie. For instance football is important in Germany and watching the matches also the world cups is a ritual for most of the people. By chance, the Italy 1990 FIFA World Cup made champion the Germany and the winner was celebrated among the people from East and West together for the first time. The supporters are also able to watch the matches from their TVs with satellite 
antennas which also allows them to watch channels all around the world. Alex is obliged to wind up his own TV repair shop and starts to a job for marketing satellites in a TV company. Alex can't explain these changings to his mother "how heroes of work became unemployed" along with the re-unification period. This free market rapidly penetrates to daily lives of Easterners. Some featuring brands like Burger King, Coca Cola, West and Ikea are shown in the movie which compel to pull the local products out of market. One of these quitted brand is the Spreewald Pickles. The Mother used to like to eat these pickles but the brand doesn't produce the pickles anymore. In order to continue her old life, Alex isolates his mother in her room with its old decoration and finds the foods of East German made brands. Finding Spreewald Pickles requires a great effort for Alex, we observe this effort throughout the movie. He finds some old packages of pickles and serves to his mother with new 'western' pickles in it (Figure 3). This pickle metaphor makes us to think about the old and the new, the ambiguity of consumption practices that emerges all of a sudden within a society and cause to disappear the habits that we belong previously.

When the Berlin Wall falls, the free capitalist life standards of West side influence the Easterners. Concurrently, the country becomes a stage of the images of consumption culture. For the Mother, seeing a Coca Cola advertisement on an apartment block from her room's window is an unbelievable event in her country. Again her family covers up the situation with white lies however this is a shocking encounter for her (Figure 4).

It is possible to increase the list. For instance the daughter, Ariane starts working at Burger King drive-through after giving up her education and she feels freer to discover the new cultures, new people that she has never met before. In one of Ariane's scenes, she and her 
husband are trying to dance with an oriental music dressed in traditional costumes. We can see that not only the costumes are belong to the orient but also the decoration of the room has been adapted to this culture. (Figure 5-6). Under the influence of these changings Ariane is a bit nervous about making role to her mother that everything is as before in the German Democratic Republic days. She doesn't want to wear old dresses or use old-styled things and her brother's endeavor doesn't make sense to her because she has adapted herself to the 'new' with her choices.

In the same scene with the Mother goes out from her room, additional to a flying Lenin statue, she encounters with the radical intruders to her city. She notices a Nazi symbol in the elevator cabin, at outside she meets with people from West Germany, she notices BMW cars, IKEA advertisements and old furniture clustered on the corners of the streets. Ironically by the time she firstly gets up from her bad and starts walking; her granddaughter Paula also starts walking and at the same time a zeppelin which is painted with a poster of West branded cigarettes disappears just then the Mother stands in front of the window. The director makes us to think who is old and who is young by interacting the oldest and the youngest characters of the movie in the same frame learning something together. (Figure 7).

\section{Concluding Remarks}

The values may have slippery meanings and can be reconsidered by people in modern era. Good Bye Lenin! movie displays the post-socialist period of East Germany through an idealist and traditional mother character in the last days of her life. The relation between mother and son is very strong that the son, Alex constitutes a fake world for his mother where is isolated from the real transformations of the country. Alex lives in the middle of the changings, while 
trying to pretend his mother as nothing has changed, he has contradictions in himself as well. In a scene while he is telling the story to audience, he says that: "The future was in our hands, uncertain and promising". On the background Alex and Lara are sitting on a ruined building and smiling (Figure 8).

The re-unification process of Germany is related directly to the words of Alex above. Integration of the practices of capitalism to the social life makes the future more ambiguous but still hopeful. Everything becomes unfashionable in a while and people start to feel full of desire for purchasing. The commodities of furniture, clothes, food and technology are all in a need of renewal. On one hand this desire is related with freedom issues, on the other hand it causes dissolution of the values and ambiguity of meanings.

Simultaneously, the Berlin Wall falls and the country unites; Alex regains his father who he supposed, he was abandoned by him 12 years ago. When he meets with his sister and brother, he notices that they are watching one of his favorite cartoon movie from his childhood. We can get the message from his eyes in this scene, maybe something doesn't change although there are boundaries in between them.

\section{BIBLIOGRAPHY}

Berman, Marshall. All that is Solid Melts into Air: The Experience of Modernity. New York, Penguin Books, 1982.

Featherstone, Mike. "Preface to the Second Edition". In, Consumer Culture and Postmodernism, London: Sage Publications, 2007. 
Featherstone, Mike. “Theories of Consumer Culture”. In, Consumer Culture and

Postmodernism, p. 14-27. London: Sage Publications, 2007.

Halbwachs Maurice, "Chapter 3: The Reconstruction of the Past," pp.46-51; "Chapter 4:

The Localization of Memories," pp.52-53. In On Collective Memory. Chicago: The University of Chicago Press, 1992.

Hobsbawm Eric and Ranger Terence, The Invention of Tradition, NY, Cambridge University Press, 1983.

Öncü, Ayşe. "The myth of the 'ideal home' travels across cultural borders to Istanbul." In Space, Culture and Power: New identities in Globalizing Cities. London: Zed Books, 1997. p. 56-72.

\section{ENDNOTES}

${ }^{1}$ Berman, Marshall. All that is Solid Melts into Air: The Experience of Modernity. New York, Penguin Books, 1982.

${ }^{2}$ Featherstone, Mike. "Preface to the Second Edition". In, Consumer Culture and Postmodernism, p. xiii. London: Sage Publications, 2007.

${ }^{3}$ Marx, Karl. "Das capital. Volume 1. Translated by Samuel Moore and Edward Aveling." The Marx-Engels Reader (2005)

${ }^{4}$ Featherstone, Mike. “Theories of Consumer Culture”. In, Consumer Culture and Postmodernism, p. 14. London:

5 Ibid. Sage Publications, 2007.

${ }^{6} \mathrm{http}: / /$ zenfloyd.blogspot.com.tr/2009/11/goodbye-lenin-sinemada-hipergerceklik.html

${ }^{7}$ Öncü, Ayşe. "The myth of the 'ideal home'travels across cultural borders to Istanbul." In Space, Culture and

8 ibid. Power: New identities in Globalizing Cities. London: Zed Books, 1997. p.: 56-72.

${ }^{9}$ ibid.

${ }^{10}$ Maurice Halbwachs, "Chapter 3: The Reconstruction of the Past,” pp.46-51; "Chapter 4: The Localization of Memories,” pp.52-53. In On Collective Memory. Chicago: The University of Chicago Press, 1992.

11 ibid.

12 ibid

${ }^{13}$ Eric Hobsbawm and Terence Ranger, The Invention of Tradition, NY, Cambridge University Press, 1983.

14 ibid

15 ibid

16 ibid

17 ibid 


\section{FIGURE LIST}




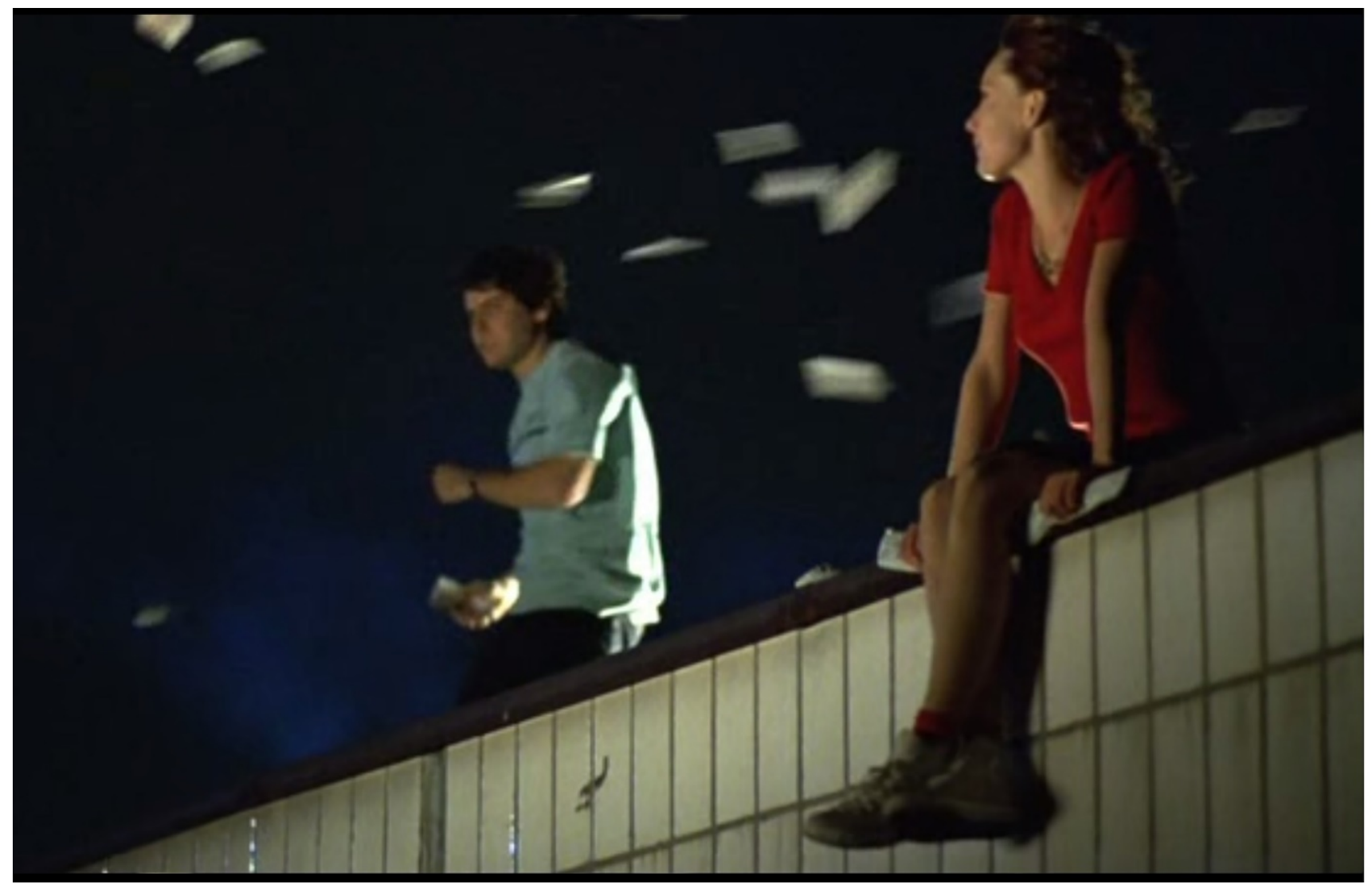

Figure 1 Alex throws the old money about.
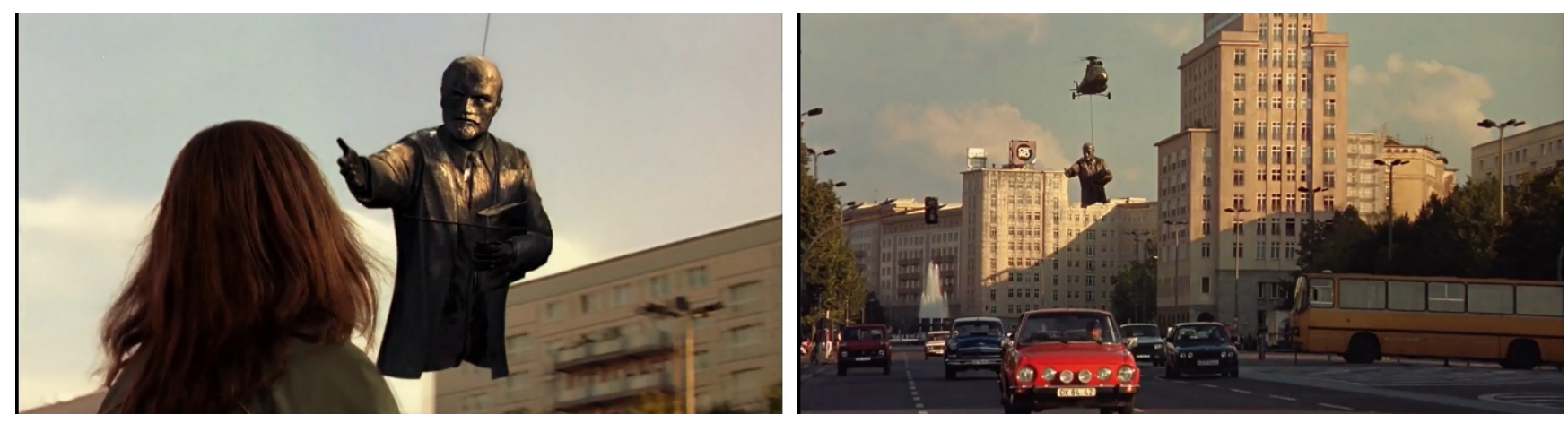

Figure 2 Mother and the flying Lenin 


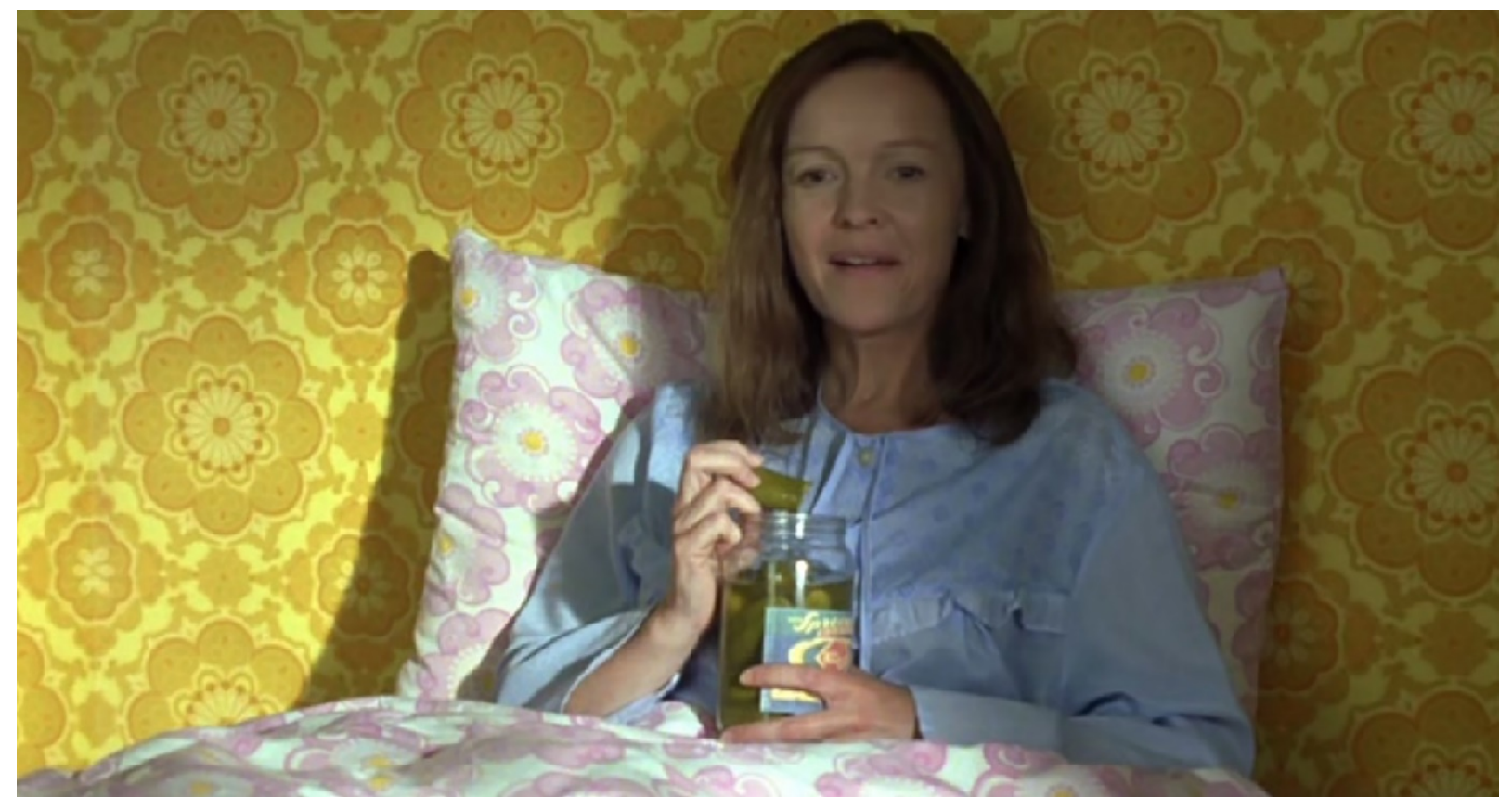

Figure 3 Mother supposes that she eats Spreewald pickles.

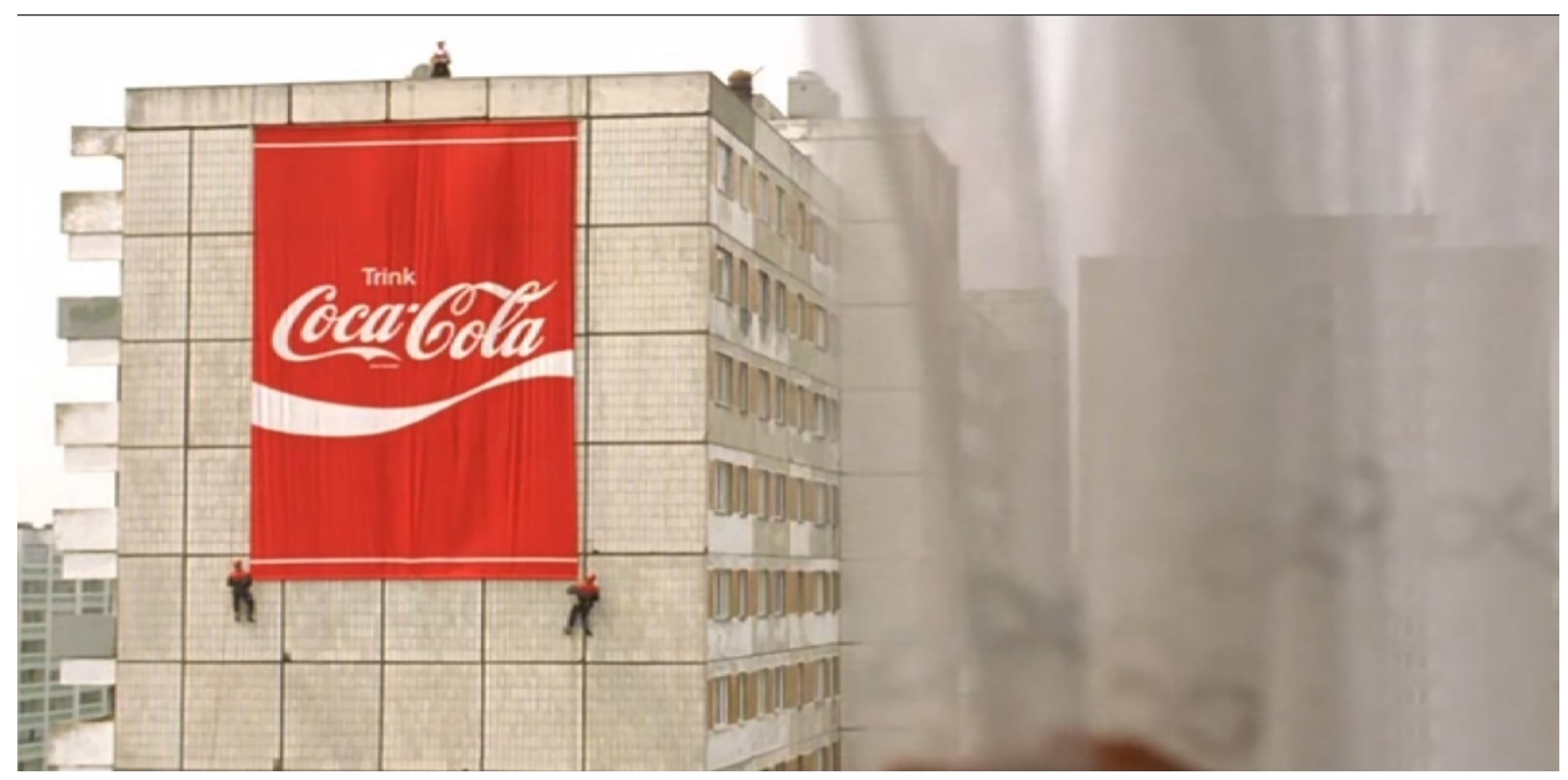

Figure 4 The rise of the Coca Cola advertisement from the Mother's window. 

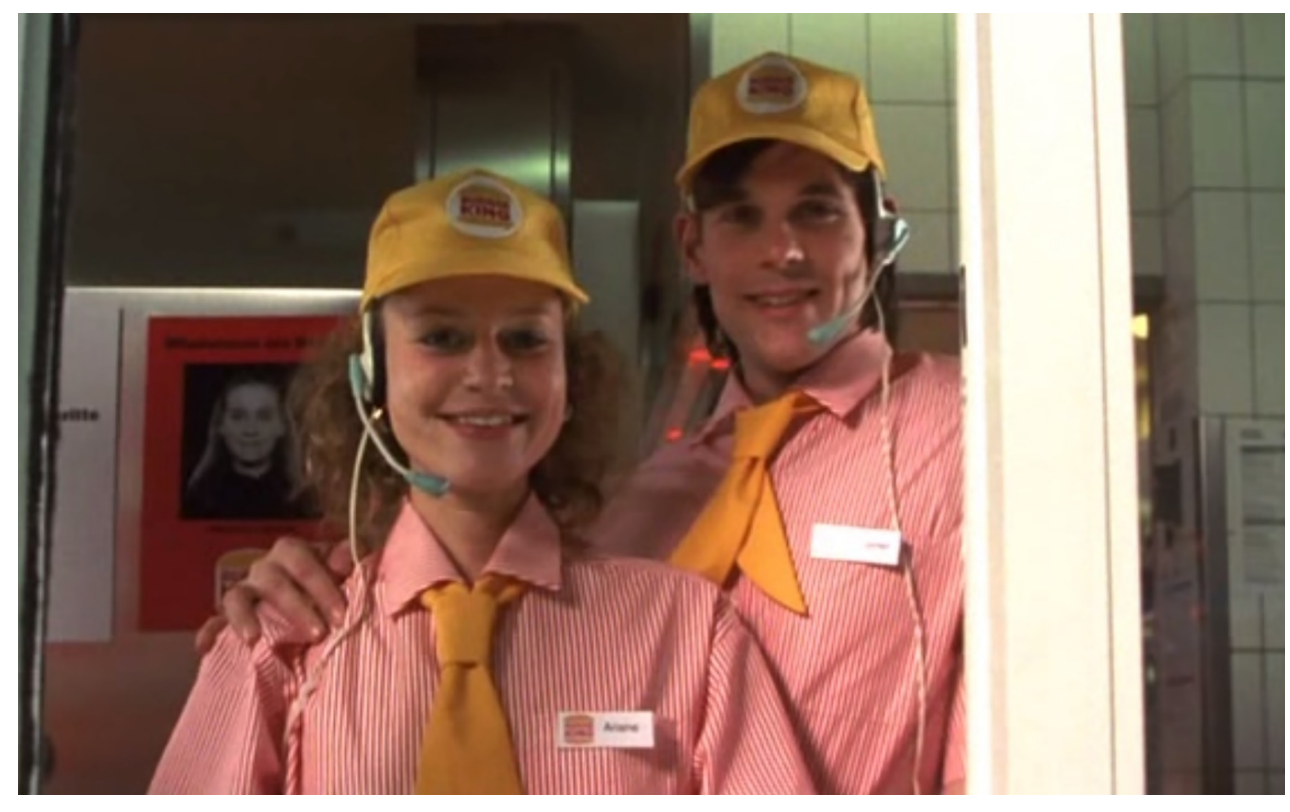

Figure 5 Ariane works at Burger King

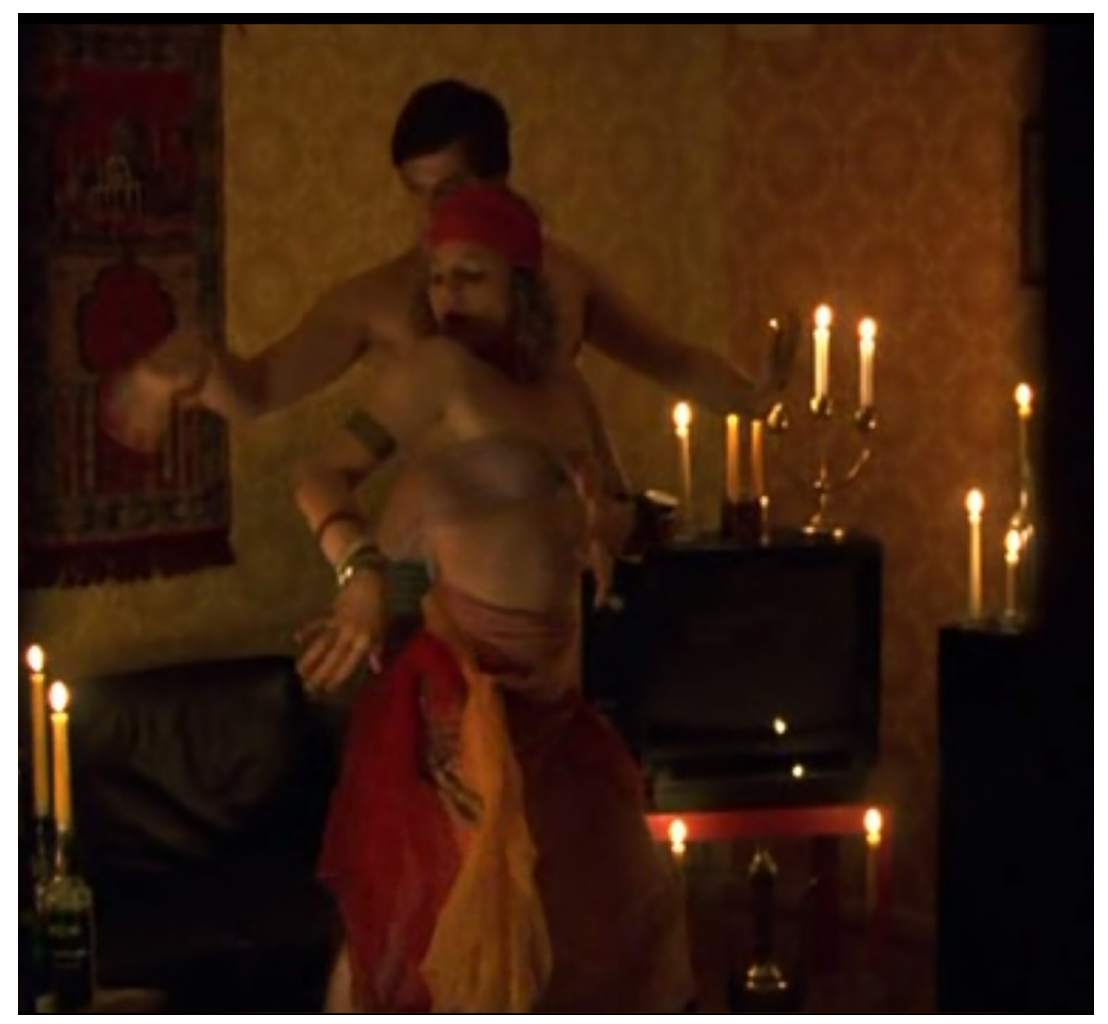

Figure 6 Ariane and her husband make belly dance. 


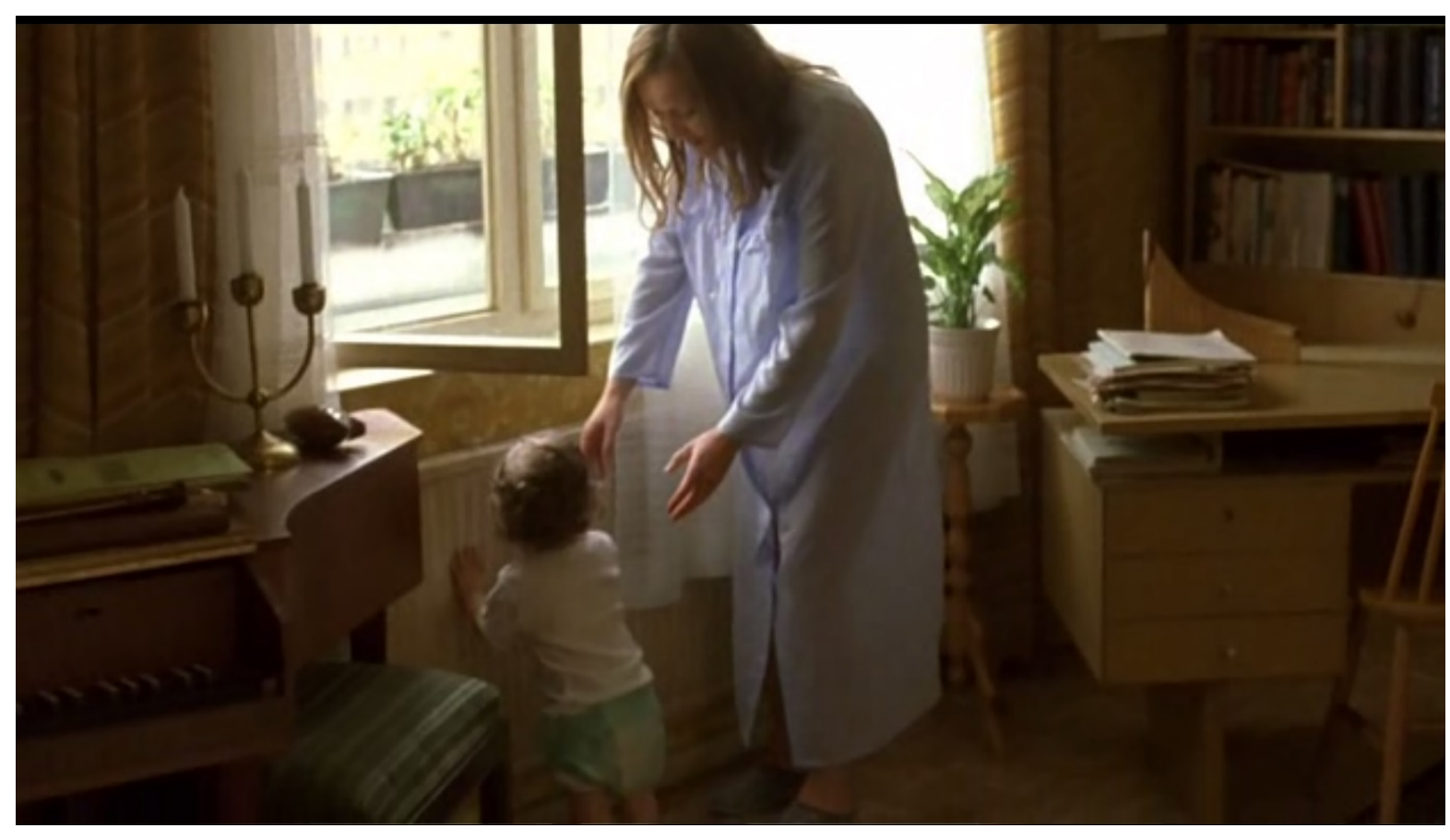

Figure 7 Grandmother and granddaughter start to walk together.

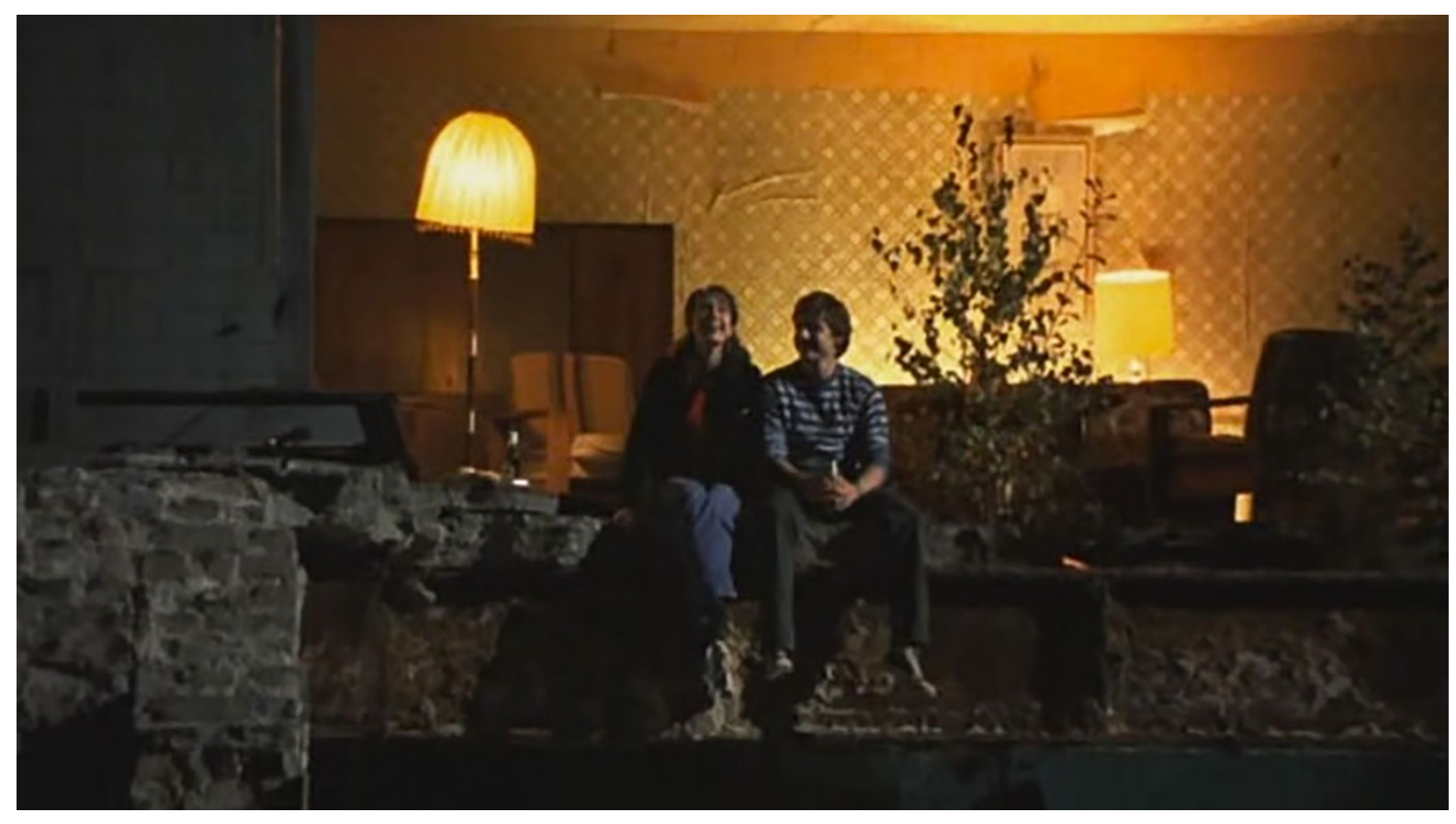

Figure 8 Alex and Lara sitting on a ruined building. 